Wahana Didaktika Vol. 18 No.2 Mei 2020 : 120-131

\title{
SISTEMATIKA PENILAIAN AUTENTIK DALAM PEMBELAJARAN DARING DI RUMAH LEWAT TELEVISI SAAT TERJADINYA COVID-19
}

\author{
Oleh: Shinta Amelia, Titin Tursina, Sibghatun Nikmah, Fuaddilah Ali Sofyan \\ (Fakultas Ilmu Tarbiyah dan Keguruan, UIN Raden Fatah Palembang) \\ Email: shintaamelia538@gmail.com
}

\begin{abstract}
Abstrak
Artikel ini bertujuan untuk mendeksripsikan sistematika penilaian autentik dalam pembelajaran daring dirumah lewat televisi saat terjadinya covid 19 sebagai alternatif pemecahan masalah dalam penilaian autententik saat ini. Penelitian ini menggunakan pendekatan kualitatif dengan latar kegiatan yaitu penilaian autentik pada siswa yang bernama Aldy Prayoga kelas 6 di SDN 3 Surya Adi kec. Mesuji. kab. OKI. Teknik pengumpulan data yang digunakan adalah observasi, wawancara, dan dokumentasi. Teknik Analisis data yang digunakan adalah reduksi data, penyajian data, dan penarikan kesimpulan. Adapun hasil penelitian ini menunjukkan bahwa (1) pembelajaran daring pada saat ini cukup membantu meskipun kurang efektif dalam proses pembelajaran, (2) sistematika pembelajaran autentik disesuaikan dengan kondisi pada saat proses pembelajaran karena penilaian ini dilakukan dengan menggunakan daring, (3) sistematika pembelajaran lewat televisi pada saat ini cukup baik meskipun lebih efektif apabila pembelajaran dilakukan di sekolah (4) kendala yang dihadapi saat belajar daring dirumah adalah mati lampu, memerlukan paket data internet dan pembelajaran lebih sulit.
\end{abstract}

Kata Kunci: Penilaian Autentik, Pembelajaran Daring dan Covid -19

\section{SYSTEMATIC AUTHORIC ASSESSMENT IN LARGE TEACHING IN TELEVISION HOUSE WHEN COVID-19 HAPPENED}

\begin{abstract}
This article aims to describe the authentic mathematics assessment sitematics in online learning at home via television when covid 19 occurs as an alternative to solving problems in authentic assessment today. This study uses a qualitative approach to the setting of activities namely authentic assessment of students named Aldy Prayoga grade 6 at SDN 3 Surya Adi kec.Mesuji. kab.OKI. Data collection techniques used were observation, interviews, and documentation. Data analysis techniques used are data reduction, data presentation, and drawing conclusions. The results of this study indicate that (1) online learning is currently quite helpful although it is less effective in the learning process, (2) authentic learning systematically adjusted to the conditions during the learning process because this assessment is done using online, (3) systematic learning via
\end{abstract}


television at this time is quite good although it is more effective if learning is done at school (4) the constraints faced when studying online at home are blackouts, requiring internet data packages and learning is more difficult.

Keywords: Authentic Assessment, Online Learning and Covid -19

\section{A. PENDAHULUAN}

Pendidikan merupakan kebutuhan mutlak manusia sepanjang hayat. Setiap manusia membutuhkan pendidikan, sampai kapanpun, dimanapun ia berada. Pendidikan sangat penting, sebab tanpa pendidikan manisia akan sulit berkembang dan bahkan terbelakang. Melalui pendidikan seseorang akan mendapatkan pengetahuan, keterampilan, dan pengalaman yang dapat meningkatkan kualitas dirinya dan yang berguna tidak hanya dirinya tetapi juga bagi orang lain. Pendidikan berkaitan erat dengan segala sesuatu yang berhubungan dengan perkembangan fisik, kesehatan, keterampilan pikiran, perasaan, kemauan, sosial, sampai pada perkembangan iman (Rohmah, 2017).

Penilaian autentik adalah kegiatan menilai peserta didik yang menekankan pada proses dan hasil dengan berbagai instrumen penilaian yang disesuaikan dengan tuntutan kompetensi yang ada di standar kompetensi atau kompetensi inti dan kompetensi dasar. Penilaian autentik mengacu pada pencapaian hasil belajar didasarkan pada skor yang diperoleh terhadap skor ideal bukan dibandingkan dengan peserta didik lain. Dalam penilaian autentik guru melakukan penilaian kompetensi dasar, kompetensi inti dan standar kompetensi lulusan (Slameto, 2010).

Pembelajaran daring merupakan pembelajaran yang dilakukan tanpa melakukan tatap muka melalui platform yang telah tersedia. Pembelajaran daring harus menjadi penyandaran bagi guru bahwa peran mereka saat ini sebagai guru yang hanya menstansfer pengetahuan suatu saat akan tergantikan oleh guru yang lebih canggih yaitu guru mesin. Media untuk mendapatkan ilmu pengetahuan saat ini sudah sangat banyak, salah satu contohnya adalah televisi. Pembelajaran daring merupakan salah satu alternatif kebijakan dari pemerintah dalam upaya 
memberikan kemudahan dan agar proses pendidikan dapat terus berjalan meskipun tidak langsung bertatap muka dan dilingkungan sekolah ditengahtengah terjadinya wabah pandemi covid-19 pada saat ini. Seperti yang kita ketahui pada saat ini dengan adanya covid -19 (corona virus deseases-19) yang turut mengubah dunia pendidikan, mulai dari metode pembelajaran, penganggaran, hingga sasarannya.

Dalam proses belajar misalnya dulu, siswa dan guru bertatap muka langsung untuk proses belajar-mengajar secara langsung, kini setelah pandemi Covid -19 merundung Indonesia, belajar mesti dilakukan dari jarak jauh atau secara daring. Pendidikan juga bukan hanya diukur saat ujian, melainkan juga menghadirkan solusi atas persoalan yang terjadi. Dengan adanya perubahan cara belajarmengajar pada saat ini dengan menggunakan daring ini sehingga membutuhkan adaptasi dari semua pihak baik guru, siswa, serta orang tua siswa agar kegiatan belajar mengajar dapat tetap berjalan efektif dan dapat tercapainya tujuan belajar.

Televisi merupakan media elektronik yang mampu menayangkan gambar bergerak atau video. Perangkat televisi saat ini sangat mudah ditemukan dan sudah menjadi perangkat rumah tangga yang wajib dimiliki setiap rumah dan keluarga. Televisi mampu menyampaikan informasi dan pesan melalui siaran langsung maupun siaran yang telah terprogram. Acara atau program TV yang paling digemari saat ini tentunya adalah acara yang bertemakan hiburan. Selain acara yang bertema hiburan, televisi juga mampu menyiarkan acara-acara yang mendidik seperti pengetahuan atau sains.

Dengan kemampuan ini, maka televisi dapat dimanfaatkan sebagai salah satu sumber atau media pembelajaran. Siaran televisi bahkan juga dapat diprogram untuk membahas dan menayangkan siaran tentang materi pembelajaran tertentu. TVRI merupakan contoh stasiun TV di Indonesia yang menyajikan siaran-siaran yang membahas materi pembelajaran. TVRI yang sudah disebutkan tadi mengkhususkan program siarannya untuk siaran dengan topik-topik pendidikan dan pembelajaran, jenis stasiun televisi ini dinamakan dengan Televisi Pendidikan. 
Arsyad (2013:53) dalam buku Media Pembelajaran ada banyak sekali keuntungan menggunakan televisi sebagai media pembelajaran. Beberapa keuntungan dari penggunaan televisi sebagai media pembelajaran antara lain adalah:

a. Televisi dapat memancarkan berbagai jenis bahan audio-visual termasuk gambar-gambar diam, film, objek, spesimen, dan drama.

b. Televisi bisa menyajikan model dan contoh-contoh yang baik bagi siswa.

c. Televisi dapat membawa dunia nyata ke rumah dan ke kelas-kelas, seperti orang, tempat-tempat, dan peristiwa melalui penyiaran langsung atau rekaman.

d. Televisi dapat memberikan kepada siswa peluang untuk melihat dan mendengarkan diri-sendiri.

e. Televisi dapat menyajikan program-program yang dapat dipahami oleh siswa dengan usia dan tingkatan pendidikan yang berbeda-beda.

f. Televisi dapat menyajikan visual dan suara yang amat sulit diperoleh pada dunia nyata.

g. Televisi dapat menghemat waktu guru dan siswa, disamping itu televisi merupakan cara yang ekonomis untuk menjangkau sejumlah besar siswa pada lokasi yang berbeda-beda untuk penyajian yang bersamaan.

Namun meskipun telah menggunakan televisi sebagai media dalam proses pembelajaran, akan tetapi terkadang siswa masih mengalami kesulitan dalam memahami suatu materi dalam pembelajaran sehingga peran orang tua sangat dibutuhkan dalam proses pembelajan tersebut.

Berdasarkan observasi yang telah dilakukan peneliti pada siswa yang bernama Aldy Prayoga kelas 6, di SDN 3 Surya Adi kec.Mesuji. kab.OKI, terdapat permasalahan yaitu, siswa masih mengalami kesulitan dalam memahami suatu materi dalam pembelajaran. Dari observasi tersebut peneliti menemukan beberapa masalah yang dihadapi siswa tersebut, adapun permasalahanpermasalahanya dalam belajar menggunakan media televisi yaitu, siswa sulit untuk memahami penjelasan materi yang disampaikan oleh guru karena singakat 
dan cepat tidak seperti disekolah guru menyampaikan materi dengan jelas luas dan terkadang dikaitkan dengan kehidupan sehari-hari serta tidak bisa bertanya atau mengulang kembali materi yang telah disampaikan oleh guru yang mengajar di televisi.

\section{B. METODOLOGI PENELITIAN}

Penelitian ini menggunakan metode penelitian kepustakaan karena persoalan penelitian yang peneliti tulis hanya bisa dijawab lewat penelitian pustaka dan sebaliknya tidak mungkin mengharapan datanya dari riset lapangan. Peneliti dalam melakukan penelitian harus memperhatikan langkah-langkah penelitian kepustakaan, adapun menurut Mestika Zed langkah-langkah penelitian kepustakaan adalah sebagai berikut:

1) Menyiapkan alat perlengkapan,

2) Menyusun bibliografi kerja,

3) Mengatur waktu,

4) Membaca dan membuat catatan penelitian (Zed, 2004:17).

Berdasarkan langkah-langkah penelitian kepustakaan, maka langkahlangkah kegiatan penelitian yang akan peneliti lakukan (Sukardi, 2007) adalah:

1) Menyiapkan Alat Perlengkapan

Pada tahap ini peneliti mempersiapkan segala sesuatu yang akan dibutuhkan dalam penelitian nantinya, seperti pensil, pena, kamera, dan alat untuk mencatat hal-hal yang menjadi bahan utama penelitian, atau pun untuk mencatat sumber buku sebagai refrensi.

2) Menyusun Bibliografi Kerja

Setelah alat perlengkapan penelitian lengkap tugas pertama dalam riset kepustakaan adalah mulai dengan menyusun Bibliografi kerja yaitu catatan mengenai bahan sumber utama yang akan digunakan untuk kepentingan penelitian. 
Sistematika Penilaian Autentik.... (Shinta Amelia, Titin Tursina, Sibghatun Nikmah, Fuaddilah A.)

3) Mengatur Waktu

Hal berikutnya yang harus diperhatikan adalah waktu, pengaturan waktu harus dilakukan untuk menghindari banyak terbuangnya waktu sia-sia. waktu penelitian harus diatur kapan mulai penelitian dan kapan harus selesainya.

4) Membaca dan Membuat Catatan Penelitian

Pada tahap terakhir ini peneliti harus membaca bahan-bahan dan membuat catatan penelitian guna kelengkapan bahan yang diperlukan dalam penelitian. karena memang penelitian kepustakaan data yang diperoleh hanya melalui buku maka dalam melakukan penelitian peneliti harus membaca dan mencatatat bahan utama dalam penelitian.

Teknik analisis data yang dipergunakan dalam penelitian ini adalah teknik analisis data kualitatif karena data yang diperoleh adalah data kualitatif jadi tidak berbentuk angka-angka, tetapi data berupa fenomena-fenomena dan kasus-kasus dalam bentuk laporan dan karangan para sejarawan, sehingga memerlukan pemikiran yang teliti dalam menyelesaikan masalah penelitian (Arikunto, 2006).

Penelitian ini merupakan penelitian instrumen kunci yang sesuai dengan karakteristik penelitian kualitatif, untuk itu peneliti secara individu akan langsung turun ketengah-tengah lapangan untuk memperoleh data dari informan, adapun yang menjadi informan di dalam penelitian ini adalah siswa yang bernama Aldy Prayoga kelas 6, di SDN 3 Surya Adi kec.Mesuji. kab.OKI. Teknik pengumpulan data yang digunakan adalah observasi, wawancara, dan dokumentasi.

Teknik Analisis data yang digunakan adalah reduksi data, penyajian data, dan penarikan kesimpulan. Data "mentah" yang terlihat dalam catatan tertulis lapangan dipilih, disederhanakan dan difokuskan. Data yang telah direduksi atau dirangkum kemudian disusun secara teratur dan terperinci dalam beberapa bagian sesuai dengan permasalahannya. Data tersebut kemudian dijabarkan dan dibandingkan antara satu dengan yang lain. kegiatan analisis sudah termasuk dalam sajian data. Setelah data direduksi, kegiatan selanjutnya menyusun kesimpulan dari data yang telah diperoleh sejak awal penelitian. 


\section{HASIL PENELITIAN DAN PEMBAHASAN}

Penelitian ini dilakukan di rumah Aldy Prayoga, yang beralamat blok E Surya Adi Kec.Mesuji. Kab.OKI. Pada hari senin, jam 09.00-09.30 mengobservasi siswa dalam proses pembelajaran dan pada jam 09.30-10.00 mewawancarai Aldy Prayoga dan Siti Alfiah selaku orang tua yang mendampingi anak dalam proses pembelajaran.

\section{a. Penerapan Pembelajaran Daring}

Berdasarkan deskripsi data penelitian di SDN 3 Surya Adi kec.Mesuji. kab. OKI sudah menerapkan penilaian autentik namun karena pada saat ini terjadi adaya wabah pandemi Covid-19 maka proses pembelajaran dialihkan menjadi daring. Pembelajaran daring sendiri merupakan pembelajaran yang dilakukan tanpa melakukan tatap muka melalui platform yang telah tersedia.

Salah satu upaya yang dilakukan pemerintah pada pendidikan mengingat pada saat ini terjadi adanya pandemi covid -19 maka pemerintah memberikan kemudahan guru dalam memberikan pembelajaran kepada siswa adalah dengan memberikan pembelajaran lewat media elektronik seperti televisi karena perangkat televisi saat ini sangat mudah ditemukan dan sudah menjadi perangkat rumah tangga yang wajib dimiliki setiap rumah dan keluarga. Televisi juga merupakan media elektronik yang mampu menayangkan gambar bergerak atau video sehingga dapat mempermudah siswa dalam belajar.

Namun pada saat proses penilaian autentik yang akan dilakukan pada saat ini terdapat beberapa kendala dalam proses penilaiannya karena guru tidak dapat memantau secara langsung dan menilai siswa karena proses pembelajan yang dilakukan pada saat ini hanya berbentuk daring meskipun penilaian autentik ini sangat penting dilakukan karena penilaian tersebut dapat digunakan untuk mengukur sejauh mana pemahaman siswa terhadap materi yang telah diajarkan dan salah satu siswa yang proses pembelajarannya menggunakan metode daring adalah Aldy Prayoga. 
Sistematika Penilaian Autentik.... (Shinta Amelia, Titin Tursina, Sibghatun Nikmah, Fuaddilah A.)

\section{b. Sistematika Penilaian Autentik}

Penilaian autentik mencakup semua aspek dengan menggunakan berbagai macam teknik penilaian. Dalam penilaian autentik yang dinilai yaitu aspek sikap spritual, sosial, aspek pengetahuan dan aspek keterampilan.

1) Penilaian Sikap Spiritual

\begin{tabular}{|c|l|c|c|}
\hline \multirow{2}{*}{ No } & \multicolumn{1}{|c|}{ Aspek Pengamatan } & \multicolumn{2}{c|}{ Keterangan } \\
\cline { 2 - 4 } & \multicolumn{1}{|c|}{$\begin{array}{l}\text { YA } \\
\text { lewat televisi dimulai. }\end{array}$} & Tidak \\
\hline 2 & $\begin{array}{l}\text { Belajar lewat televisi tepat waktu sesuai } \\
\text { jadwal pembelajaran (09.00 WIB) }\end{array}$ & \\
\hline 3 & $\begin{array}{l}\text { Menyiapkan } \\
\text { pembelajaran }\end{array}$ & \\
\hline 4 & $\begin{array}{l}\text { Belajar dengan serius atau tidak main- } \\
\text { main }\end{array}$ & \\
\hline 5 & $\begin{array}{l}\text { Mengikuti pembelajaran sampai selesai } \\
\text { (09.30 WIB) }\end{array}$ & \\
\hline \multicolumn{2}{|l|}{ Jumlah skor } & \\
\hline
\end{tabular}

2) Penilaian Diri Sendiri

\begin{tabular}{|c|l|l|l|}
\hline \multirow{2}{*}{ No } & \multicolumn{1}{|c|}{ Aspek Pengamatan } & \multicolumn{2}{c|}{ Keterangan } \\
\cline { 3 - 4 } & \multicolumn{1}{|c|}{ YA } & Tidak \\
\hline 1 & $\begin{array}{l}\text { Membaca doa sebelum pembelajaran } \\
\text { lewat televisi dimulai. }\end{array}$ & \\
\hline 2 & $\begin{array}{l}\text { Belajar lewat televisi tepat waktu sesuai } \\
\text { jadwal pembelajaran (09.00 WIB) }\end{array}$ & & \\
\hline 3 & $\begin{array}{l}\text { Menyiapkan perlengkapan } \\
\text { pembelajaran }\end{array}$ & \\
\hline 4 & $\begin{array}{l}\text { Mengikuti pembelajaran sampai selesai } \\
\text { (09.30 WIB) }\end{array}$ & \\
\hline 5 & $\begin{array}{l}\text { Tidak saling diskusi dengan teman } \\
\text { lewat chat (whatsapp dan sebagainya) }\end{array}$ & & \\
\hline
\end{tabular}


Wahana Didaktika Vol. 18 No.2 Mei 2020 : 120-131

\begin{tabular}{|c|c|c|c|}
\hline \multirow{2}{*}{ No } & Aspek Pengamatan & \multicolumn{2}{|c|}{ Keterangan } \\
\cline { 3 - 4 } & & YA & Tidak \\
\hline 6 & Mengumpul hasil belajar tepat waktu & & \\
\hline \multicolumn{2}{|c|}{ Jumlah skor } & & \\
\hline
\end{tabular}

3) Pengetahuan

\begin{tabular}{|c|l|c|c|c|}
\hline \multirow{2}{*}{ No } & \multicolumn{2}{|c|}{ Aspek Pengamatan } & \multicolumn{3}{|c|}{ Keterangan } \\
\cline { 3 - 5 } & \multicolumn{1}{|c|}{ YA } & Cukup & Tidak \\
\hline 1 & $\begin{array}{l}\text { Siswa memahami atas materi } \\
\text { yang dijelaskan di televisi }\end{array}$ & & & \\
\hline 2 & $\begin{array}{l}\text { Siswa menjawab soal-soal } \\
\text { dengan baik dan benar }\end{array}$ & & & \\
\hline \multicolumn{2}{|c|}{ Jumlah } & & & \\
\hline
\end{tabular}

\section{c. Sistematika Pembelajaran Lewat Televisi}

Berdasarkan hasil wawancara yang peneliti lakukan oleh siswa dan orang tua siswa, sistematika dalam pembelajaran daring lewat televisi yaitu dengan cara, siswa setiap hari senin-jumat mendapatkan arahan dari guru untuk melakukan pembelajaran dengan melihat televisi saluran TVRI, dimana sesuai jadwal saluran TVRI kelas VI pembelajaran dimulai dari pukul 09.00-09.30 WIB. Dalam pembelajaran tersebut terdapat penjelasan dan beberapa soal sesuai materi yang dijelaskan. Setelah siswa mencatat pertanyaan-pertanyaan yang terdapat ditelevisi, siswa dilanjutkan dengan mengerjakan soal-soal tersebut. Setelah selesai mengerjaknnya, maka hasil siswa di foto dan di kirim melalui Whatsapp secara pribadi dengan wali kelas. 
Sistematika Penilaian Autentik.... (Shinta Amelia, Titin Tursina, Sibghatun Nikmah, Fuaddilah A.)
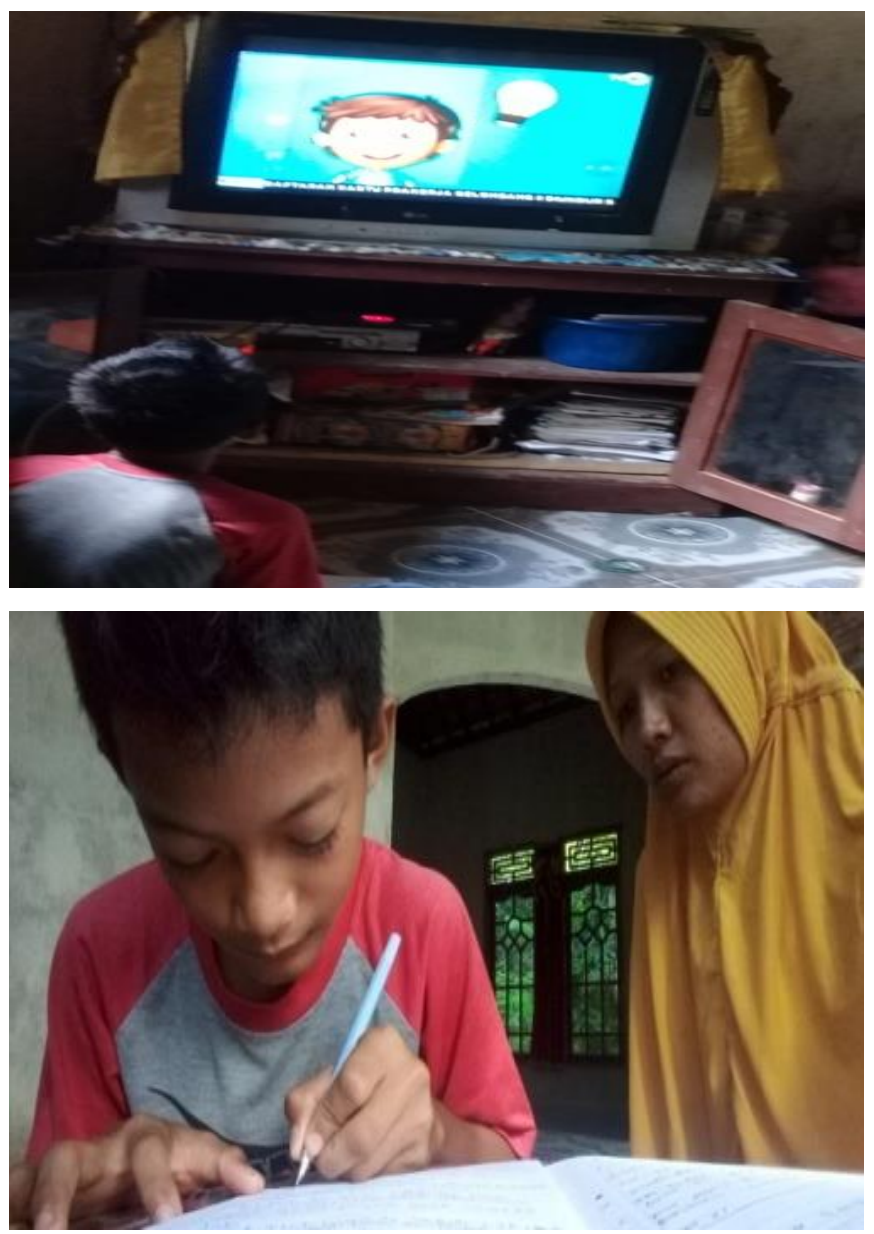

\section{d. Kendala yang Dihadapi Saat Belajar Daring di Rumah}

Berdasarkan hasil wawancara, kendala belajar daring dirumah dapat dirasakan oleh siswa dan orang tua siswa. Berikut kendala yang dihadapi:

1) Menurut siswa

a) Lebih sulit memahami materi dibandingkan belajar di sekolah

b) Jika mati lampu, siswa melihat pembelajaran lewat android

c) Memerlukan paket data untuk mengirim tugas

2) Menurut orang tua siswa

a) Jika mati lampu, siswa melihat pembelajaran lewat android

b) Memerlukan paket data untuk mengirim tugas 
c) Orang tua harus menunda pekerjaan untuk mendampingi anak, agar anak tidak merasa kebinggungan untuk memecahkan soal-soal yang tertera di televisi.

\section{SIMPULAN}

Berdasarkan hasil penelitian tentang sistematika penilaian autentik dalam pembelajaran daring dirumah lewat televisi saat terjadinya covid-19 maka dapat peneliti simpulkan bahwa Pembelajaran pembelajaran daring merupakan salah satu kebijakan pemerintah dalam menangani penyebaran covid-19 dalam pendidikan agar proses pembelajaran tetap terus aktif meskipun dilakukan dirumah, salah satu contohnya diterapkan di SDN 3 Surya Adi kec.Mesuji. kab.OKI. dan Aldy Prayoga adalah salah satu siswa yang kami teliti dalam pembelajaran daring ini.

Sistematika penilaian autentik mencakup semua aspek dengan menggunakan berbagai macam teknik penilaian. Dalam penilaian autentik yang dinilai yaitu aspek sikap spritual, sosial, aspek pengetahuan dan aspek keterampilan. Sistematika pembelajaran lewat televisi sudah cukup baik dan dilakukan setiap hari senin-jumat mendapatkan arahan dari guru untuk melakukan pembelajaran dengan melihat televisi saluran TVRI, dimana sesuai jadwal saluran TVRI kelas VI pembelajaran dimulai dari pukul 09.00-09.30 WIB.

Adapun kendala yang dihadapi dalam proses pembelajaran daring adalah apabila terjadinya mati lampu, memerlukan paket data internet, pembelajaran lebih sulit dan orang tua harus menyisihkan waktu untuk menemani anak belajar. 
Sistematika Penilaian Autentik.... (Shinta Amelia, Titin Tursina, Sibghatun Nikmah, Fuaddilah A.)

\section{DAFTAR PUSTAKA}

Arsyad, Azhar. 2011. Media Pembelajaran. Jakarta: PT Raja Grafindo Persada.

Zed, Mestika. (2004). Metode Penelitian Kepustakaan. Yayasan Obor Indonesia: Jakarta.

Rohmah, Nurhayati. (2007). Psikologi Pendidikan. Yogyakarta: UNY Press.

Slameto. (2010). Belajar dan Faktor-Faktor yang Mempengaruhi. Jakarta: Rineka Cipta.

Arikunto, Suharsimi. (2006). Prosedur Penelitian: Suatu Pendekatan Praktik. Ed.VI. Cet.13. Jakarta: Rineka Cipta.

Sukardi. (2007). Metodologi Penelitian Pendidikan. Jakarta: Bumi Aksara. 